\title{
Perempuan dalam Tayangan Iklan di Televisi
}

\author{
Oji Kurniadi
}

\begin{abstract}
As part of marketing activities, advertising played a very important role. Through the means of advertising, a product with all its characteristics and qualities was being introduced to the public. The ad creators competitively search ideas to construct an attractive ad. The depiction of women becomes one of the old-but-believed-to-be-effective-formula for such advertisings. In the world of advertising and marketing, women are not only becoming models for women products, but also for men products. Women figures were depicted beside men models in cigarettes advertising and in turn seemed problematic. A strong and unending debate has been circulating amongst public concerning advertising who significantly exploited women's sensuality. These kinds of ads are believed degraded women and create negative image for women.
\end{abstract}

Kata kunci: perempuan, iklan, televisi, eksploitasi tubuh

\section{Latar Belakang}

Keberhasilan penjualan produk ditentukan oleh banyak faktor. Diantaranya adalah bagaimana produk tersebut dipasarkan. Berikutnya keberhasilan pemasaran pun akan banyak ditentukan oleh berbagai faktor, dan salah satunya adalah iklan.

Iklan memang merupakan bagian dari kegiatan pemasaran, sedangkan pemasaran itu sendiri bertujuan untuk menciptakan pasar.

Pada dasarnya pasar merupakan sekelompok orang yang memiliki need, want, dan buy yang sama. Dengan demikian iklan menjadi senjata yang ampuh untuk menciptakan need, want, dan buy, melalui materi iklan yang impactfull maupun melalui reach, frequency, serta continuity di media yang efektif dan efisien.

Pertumbuhan iklan di televisi mengalami kegairahan setelah lesu diterpa krisis moneter di
Indonesia. Televisi selalu meraup kue iklan paling besar dibandingkan dengan media lainnya. Pengiklan berlomba-lomba memenuhi program program acara di televisi. Hal ini mengakibatkan persaingan antar - iklan, membuat persaingan antar - produk yang semakin ketat. Para pengiklan berlomba - lomba merebut perhatian pemirsa Televisi, hal ini mengingat beberapa kelebihan yang dipunyai Televisi, yaitu :

(1) Efisiensi biaya

Salah satu keunggulannya adalah kemampuan menjangkau khalayak sasaran yang sangat luas. Jangkauan masal ini menimbulkan efisiensi biaya untuk menjangkau setiap kepala.

(2) Dampak yang kuat

TV juga mampu menciptakan kelenturan bagi pekerjaan - pekerjaan kreatif dengan mengombinasikan gerakan, kecantikan, suara, warna, drama, dan humor. 
(3) Pengaruh yang kuat

TV mempunyai kemampuan yang kuat untuk memengaruhi persepsi khalayak sasaran. Kebanyakan calon pembeli lebih " percaya “ pada perusahaan yang mengiklankan produknya di TV daripada tidak sama sekali (Kasali, 1995:121 ).

Di samping ketiga faktor di atas, dengan kemampuan jangkauan yang merambah ke berbagai bentuk kehidupan masyarakat, televisi menjadi sarana yang sangat ampuh untuk menjangkau pasar sasaran, mulai dari berbagai kelompok umur, kelas sosial, gaya hidup, dan profesi; semuanya menjadi jangkauan televisi sehingga menjadi alat yang ampuh untuk memasang iklan.

Iklan pada dasarnya ditujukan untuk menyampaikan kepada kita tentang nilai dan manfaat dari produk yang diiklankan. Dalam perkembangannya iklan-iklan dewasa ini, lebih banyak berkutat dengan representasi-repensentasi dari kultural iklan daripada kualitas produk yang diiklankan. Sebagai contoh, dengan dipakainya Tamara Bleszinsky untuk iklan LUX atau Sophia Latjuba untuk iklan Giv, hal ini mencitrakan tentang konsep kecantikan melalui warna kulit putih dan wajah yang indo.

Iklan memang tidak akan terlepas dari budaya suatu masyarakat. Iklan akan tetap merepresentasikan budaya masyarakat di mana iklan tersebut merebak. Frith menyatakan bahwa iklan yang baik adalah iklan yang mampu berkomunikasi dengan kebudayaan. Dalam formulanya, iklan (advertasing) adalah sama dengan komunikasi plus kebudayaan $(\mathrm{A}=\mathrm{C}+\mathrm{C})$. Pada gilirannya, iklan bekerja dengan cara merefleksikan budaya tertentu kepada konsumen. Dengan demikian, produk yang di-iklankan tidak digambarkan sebagaimana adanya, akan tetapi produk harus menjadi bagian dari cerita budaya.

Di sisi lain Bovee ( 1976 ) mengemukakan, bahwa periklanan yang baik mengacu pada segi daya tarik bagi iklan yang terdiri atas; daya tarik pesan dalam artian kata - kata, kalimat, dan berikut daya tarik fisik, yaitu penampilan luar, ilustrasi yang menyertai iklan itu. ( Liliweri, 1992:75 )
Daya tarik fisik yang menonjolkan penampilan luar menjadi salah satu hal terpenting dalam sebuah iklan, sehingga, para pembuat dan pemasang iklan bersaing semakin ketat dalam urusan daya tarik fisik. Wanita, seringkali dijadikan model dalam iklan dengan tujuan untuk menampilkan daya tarik fisiknya tersebut.

Dalam konteks citra perempuan dalam iklan yang banyak ditayangkan televisi, maka cerita budaya berusaha untuk dibangun dengan menampilkan manipulasi tubuh wanita (outer body of women), yang menjadi sebuah tanda atau makna tertentu dari simbol-simbol tertentu yang mungkin secara stereotif melekat pada perempuan tersebut, seperti keanggunan, keindahan, kelembutan, kemanjaan, dan mungkin banyak lagi. Menurut Busby \& Leichty iklan mempergunakan tubuh wanita (the outer body of women) sebagai alat untuk menciptakan citra produk tertentu. Atau setidaknya, tubuh perempuan memiliki fungsi sebagai latar dekorasi suatu produk.

Lihatlah iklan LUX, dengan digunakannya para "selebritis" papan atas, mempunyai makna dalam benak konsumen sebagai "sabun para bintang”. Kalau melihat sejarah iklan LUX yang cukup tua (1955) ini, dengan model pertamanya Susan Hayward seorang bintang terkenal pada jamannya yang kemudian diikuti oleh bintangbintang terkenal lainnya, maka hal yang sama terjadi pada iklan LUX di Indonesia dengan digunakannya para bintang terkenal papan atas, yang mempunyai kulit putih karena memang kebetulan dia keturunan Indo. Akhirnya, simbol sebagai "sabun para bintang" melekat pada LUX, dan pada gilirannya makna sebagai sabun berkelas pun melekat pada benak setiap konsumen.

Priosoedarsono (1998) berpendapat bahwa tampilnya wanita dalam iklan memang dibutuhkan untuk memperkuat daya jual dari sebuah produk, bukan saja dalam menyampaikan sebuah pesan tetapi juga kesan terhadap produk tersebut. Lebih jauh Priosoedarsono menyatakan bahwa tampilnya wanita dalam iklan tidak lepas dari 5 elemen kemapanan, yang dijelaskan sebagai berikut;

Tampilnya wanita dalam iklan merupakan elemen yang sangat menjual, yakni Garwo. Bagi 
produk pria, kehadiran wanita merupakan salah satu syarat penting bagi kemapanan/eksistensinya. Sementara, bila marketnya wanita, kehadiran wanita merupakan wajah yang mewakili jati dirinya/ eksistensinya.

Berbagai expose yang merugikan kaum wanita bisa terjadi bila wanita ditampilkan pada elemen lainnya. Di mana wanita ditampilkan sebagai bagian dari Wismo, atau bagian dari Karyo, dan yang lebih parah bila menjadi bagian dari Turonggo dan Kukilo. Khususnya yang dua terakhir ini, tidak pelak lagi, pasti menuju rangsangan tubuh.

Memang, iklan-iklan yang ditayangkan di televisi banyak menggunakan wanita sebagai model iklan tidak hanya sabun. Dimulai dari produk yang betul-betul untuk wanita sampai pada produk yang sebetulnya tidak berkaitan dengan wanita. Banyak produk yang diiklankan yang sebetulnya pangsa pasarnya adalah laki-laki. Lihat saja, misalnya, bagaimana iklan rokok "Jarum Coklat" seorang model laki-laki, dia tidak tampil sendiri, tetapi didampingi oleh model wanita sebagai daya tariknya. Lihat pula iklan oil "Top One", sebuah iklan oli mobil yang tentunya karena berkaitan dengan kendaraan punya pangsa pasar laki-laki, namun tetap wanita menjadi model iklannya. Dan tentunya, masih banyak iklan lain yang bernasib sama, yaitu tetap menampilkan sosok wanita sebagai model sekalipun iklan tersebut produk yang dipasarkan dengan konsumen laki-laki.

Dengan banyaknya penggunaan wanita dalam iklan sebuah produk, di mana juga banyak mempertontonkan atau menjual tubuh wanita, ternyata menuai banyak pro dan kontra, yang jelas citra negatif telah melekat. Memang, dalam Deklarasi Konferensi PBB tentang wanita di Beijing, September 1995, menyatakan bahwa kendala besar bagi kaum wanita dalam perjuangannya untuk memperoleh kedudukan yang selayaknya dalam masyarakat, adalah citra negatif yang ditampilkan di media massa, khususnya dalam iklan-iklan. Pada akhirnya, menarik untuk mengkaji lebih dalam mengenai bagaimana wanita direpresentasikan melalui iklan produk untuk laki-laki yang ditayangkan dalam televisi.

\section{Pembahasan}

\subsection{Tinjauan Komunikasi Massa}

Sebagai mahkluk yang tidak dapat hidup sendiri, manusia memerlukan orang lain, oleh karena itu, manusia memerlukan komunikasi untuk berinteraksi dengan manusia lainnya. Manusia tidak dapat tidak berkomunikasi atau "we can not not communicate".

Komunikasi sudah menjadi kebutuhan manusia yang esensial. Kehidupan kita sehari-hari sangat dipengaruhi oleh komunikasi yang kita lakukan dengan orang lain, termasuk pesan-pesan yang disampaikan oleh orang lain dari jarak jauh yang tidak kita kenal.

Berelson \& Gary H. Stainer menyampaikan pengertian komunikasi sebagai berikut:

Communication is the transmission of information,

ideas, emotions, skills, etc., by the use of symbols

- words, pictures, figures, graphs, etc.,it is the act

of process of transmission that is usually called communication.

Komunikasi adalah penyampaian informasi, gagasan, emosi, keterampilan, dan sebagainya, dengan menggunakan lambang - lambang, kata kata, gambar, bilangan, grafis, dan lain - lain. Kegiatan atau proses penyampaianlah yang biasanya dinamakan komunikasi (dalam Effendy, 1986:62).

Demikian pula untuk seorang pedagang atau orang yang mempunyai produk, memerlukan komunikasi untuk memperkenalkan produk yang dijualnya itu. Di sinilah pentingnya periklanan atau memasang iklan dengan tujuan untuk menyampaikan informasi tentang produk yang dijual.

Pada perkembangan komunikasi, peranan media massa baik elektronik maupun cetak, sangat penting. Terbukti dengan kemajuan teknologi, membuat komunikasi massa menjadi suatu kebutuhan akan informasi. Rahmadi (1990:5) menjelaskan bahwa pada abad modern ini, masyarakat tidak dapat lagi hidup tanpa informasi. Dengan kata lain, berita atau informasi sudah menjadi kebutuhan manusia modern.

Joseph. A. DeVito (1978:442) mengemukakan 
dua pengertian komunikasi massa, yaitu : pertama, komunikasi massa adalah komunikasi yang ditujukan kepada massa, kepada khalayak yang luar biasa banyaknya. Kedua, komunikasi massa adalah komunikasi yang disampaikan melalui media, baik audio maupun visual, dalam hal ini media massa seperti Televisi, radio, surat kabar, majalah film, buku - buku, dan tape recorder.

Dari uraian di atas, maka dapat disimpulkan bahwa komunikasi yang ditujukan kepada massa dengan menggunakan suatu media, yaitu media massa, disebut komunikasi massa.

Proses komunikasi yang dilakukan melalui media massa berbeda dengan proses tatap muka yang terkesan sederhana. Dalam komunikasi massa, proses yang dilalui menjadi rumit, karena melibatkan berbagai pihak, bagaimana peliknya komunikasi massa, Werner I. Severin dan James W. Tankard, Jr. dalam bukunya, Communications Theories, Origins, Method, Uses, mengatakan sebagai berikut:

Mass communications is part skill, part art, and part science. It is a skill in the sense that it involves certain fundamental learnable techniques such as focusing a television camera, operating a tape recorder or taking notes during an interview. It is art writing a script for a television program, developing an aesthetic layout for a magazines and or coming up with a catchy lead for a news story. It is a science in the sense that there are certain principles involved in how communication works that can be verivied and used to make things work better.

Komunikasi massa adalah sebagian keterampilan, sebagian seni, dan sebagian ilmu. Ia adalah keterampilan dalam pengertian bahwa ia meliputi teknik-teknik fundamental tertentu yang dapat dipelajari seperti memfokuskan kamera televisi, mengoperasikan tape recorder, atau mencatat ketika berwawancara. Ia adalah seni dalam pengertian bahwa ia meliputi tantangan-tantangan kreatif seperti menulis skrip untuk program televisi, mengembangkan tata letak yang estetis untuk iklan majalah, atau menampilkan teras berita yang memikat bagi sebuah kisah berita. Ia adalah ilmu dalam pengertian bahwa ia meliputi prinsip-prinsip tertentu tentang bagaimana berlangsungnya komunikasi yang dapat dikukuhkan dan dipergunakan untuk membuat berbagai hal menjadi lebih baik (dalam Effendy, 1998: 21).

\subsection{Televisi dan Iklan}

Dalam era perkembangan media massa, kita hidup dengan berlimpahnya informasi. Hal ini tidak lain karena "ledakan informasi" yang bertubi-tubi dibawa media massa ke dalam rumah kita. Televisi menjadi sebuah "kotak ajaib" yang diletakkan begitu khusus di ruang keluarga rumah kita. Tidak heran kalau Gerbner menyebut tayangan televisi sebagai "agama baru" yang menggantikan agama tradisional.

Relasi kita dengan televisi tidak dapat dihindarkan. "Ledakan informasi" membuat kita terperangkap dalam banjirnya arus informasi. Tayangan televisi (informasi, iklan, dan hiburan) semakin bervariasi dan penuh daya pikat, sehingga sering kali kita terpaku dan hanyut dalam dramatisasi tayangan televisi.

Sudah merupakan fakta bahwa televisi sebagai media massa mempunyai daya tarik yang cukup kuat bagi khalayaknya. Hal ini dikatakan Skornis, dibandingkan dengan media massa lainnya, televisi nampaknya mempunyai sifat istimewa :

Televisi merupakan gabungan dari media dengar yang bersifat politis seperti yang diungkapkan di atas, bisa pula informatif, hiburan, dan pendidikan, atau bahkan gabungan dari ketiga unsur tersebut. Televisi menciptakan suasana tertentu, yaitu: para pemirsanya dapat melihat sambil duduk santai tanpa kesengajaan untuk menyaksikannya. Penyampaian isi pesan seolah olah langsung antara komunikator dan komunikan. Informasi yang disampaikan oleh televisi akan mudah dimengerti dengan jelas, karena terdengar secara audio dan terlihat secara visual (Kuswandi, $1996: 8$ ).

Periklanan, sesungguhnya, sama tuanya dengan peradaban manusia itu sendiri, dan sudah sejak lama digunakan sebagai wahana untuk mengomunikasikan kebutuhan membeli atau menjual berbagai produk barang dan jasa. Sebagai konsekuensinya, institusi periklanan mengalami proses perubahan yang tak henti-hentinya dalam 
mewakili berbagai produk barang, jasa, pasokan, dan bentuk-bentuk permintaan baru, diiringi dengan media dan teknik baru guna mengkomunikasikannya. Secara sengaja maupun tidak disengaja, kita setiap saat dibanjiri iklan lewat media televisi, radio, surat kabar, majalah, ataupun media-media lainnya; dan tampaknya, iklan telah menjadi bagian dalam kehidupan kita.

Secara etimologi, iklan berasal dari kata "advertientie" dalam bahasa Belanda, atau advertising dalam bahasa Inggris, advere dari bahasa Latin yang berarti mengoperkan pikiran atau gagasan (iklan) kepada pihak lain. Sementara Rhenald Kasali mendefinisikan iklan sebagai pesan yang menawarkan suatu produk yang ditujukan kepada masyarakat lewat suatu media “. ( Kasali, 2000: 145 )

Pada sisi lain, Schindler (dalam Suhandang, 2005:15) menjelaskan bahwa periklanan adalah salah satu metode untuk memperkenalkan barang, jasa, atau gagasan kepada publik. Pada Akhirnya, dapat disimpulkan bahwa iklan atau periklanan adalah salah satu teknik komunikasi massa melalui penggunaan media dengan membayar ruangan atau waktu yang disediakan untuk menyiarkan atau menyampaikan pesan tentang barang atau jasa yang ditawarkan oleh si pemasang iklan.

Dalam rangka penyewaan ruang atau waktu untuk mengiklankan produk yang dijual, maka Televisi menjadi pilihan yang tepat. Televisi yang berifat audio visual mempunyai beberapa kelebihan dibanding dengan media lain dalam rangka periklanan.

Jeffkins menyebutkan beberapa kelebihan iklan di televisi:

(1) Iklan di televisi berkesan realistis. Iklan yang disampaikan secara visual akan menancapkan kesan yang lebih dalam, sehingga khalayak begitu melihat produknya akan segera mengingat iklannya di televisi

(2) Iklan di televisi membuat khalayak lebih siap memberi perhatian

(3) Iklan di televisi mampu menyajikan repetisi (pengulangan). Iklan di televisi dapat ditayangkan berulang-ulang hingga mencapai frekuensi yang cukup untuk membuat pengaruh iklan itu nampak pada diri audiens. (Jeffkins, 1997: 121 )

Hampir $55 \%$ dari seluruh periklanan nasional dikeluarkan untuk beberapa bentuk televisi. Konsumen mengatakan bahwa mereka, sebagian besar, mengenal produk baru melalui televisi. Ini salah satu bukti bahwa media televisi akan mempunyai peranan yang besar terhadap kenaikan penjualan produk yang diiklankan melalui televisi. Hal ini, tentunya, dilandasi oleh sifat dari televisi itu sendiri seperti dijelaskan oleh Suhandang (2005:89), yaitu: pertama immediacy, di mana penyampainnya yang langsung tanpa mengenai batas jarak dan waktu. Televisi membawa gambar beserta suara ke tempat-tempat yang berjauhan dengan pengiriman serta penerimaannya terjadi saat bersamaan.

Sifat kedua televisi, yaitu intimacy, di mana siarannya dapat diikuti dan dinikmati dalam lingkungan kekeluargaan. Pictorial, merupakan sifat yang ketiga di mana televisi merupakan medium yang menggunakan cara komunikasi dengan gambar-gambar bergerak disertai suara, sehingga memudahkan orang dalam memahaminya.

Di samping kelebihan dari sisi televisi itu sendiri, dari sisi khalayak menonton, mengkonsumsi iklan ditelivisi memang kegiatan yang menyenangkan dan murah dibandingkan dengan biaya yang dikeluarkan bila kita melihat iklan di majalah, surat kabar, dan film.

Iklan memang bertujuan untuk menyampaikan informasi sebuah produk. Dalam proses pembuatannya, tentu banyak dipengaruhi oleh berbagai faktor. Diantaranya adalah kondisi masyarakat pada saat iklan tersebut dibuat. Beberapa penelitian menjelaskan bahwa iklan yang ditampilkan banyak memperlihatkan nilai-nilai kehidupan masyarakat pada zamannya, sehingga, periklanan dianggap sebagai sebuah cermin dari kehidupan masyarakat.

\subsection{Perempuan dan Iklan di Televisi}

Iklan tidak akan terlepas dari budaya suatu masyarakat. Iklan akan tetap merepresentasikan budaya masyarakat di mana iklan tersebut merebak. 
Bahkan, di era globalisasi informasi saat ini, iklan mereprensentasikan gaya hidup dari masyarakat pada jamannya. Iklan bekerja dengan cara merefleksikan budaya tertentu kepada konsumen, sehingga produk yang di-iklankan tidak digambarkan sebagaimana adanya, akan tetapi menjadi bagian dari cerita budaya. Iklan dengan demikian, telah menjadi semacam "saluran hasrat" (channel of desire) manusia dan sekaligus "saluran wacana" (channel of discourse) mengenai konsumsi dan gaya hidup.

Memang, dalam era globalisasi, khususnya informasi, maka iklan akan berperan besar dalam membentuk budaya citra (image culture) dan budaya cita rasa (taste culture). Hal ini di sebagai akibat gempuran iklan yang menawarkan gaya visual yang memesona dan memabukkan, iklan merepresentasikan gaya hidup dengan menanamkan secara halus pentingnya citra diri. Marshall Mcluhan menyebutnya sebagai karya seni terbesar abad ke-20, yang selanjutnya menjadikan iklan sebagai industri budaya (cultural industry) masa kini yang penting.

Pada gilirannya, media, khususnya televisi, melalui iklan yang ditayangkan sesungguhnya memainkan peran khusus dalam memengaruhi budaya tertentu melalui penyebaran informasinya. Peran media sangat penting karena menampilkan sebuah cara dalam memandang realita. Para produser mengendalikan isi medianya melalui caracara tertentu untuk menyandikan pesan-pesan.

Konsekuensi penyampaian iklan lewat tayangan di media televisi, menurut Barker (2005:360), secara perlahan tapi pasti menjadikan televisi sebagai sumber bagi pembentukan identitas kultural, dan pemirsa juga menggunakan identitas dan kompetensi kultural mereka untuk mendekode program dengan cara khas masingmasing. Seiring dengan mengglobalnya televisi, perannya dalam pembentukan identitas-identitas etnis dan nasional menjadi semakin penting.

Dengan demikian dalam iklan inilah kita dapat melihat bagaimana perempuan itu diposisikan dalam kerangka budaya kita. Tayangan iklan di televisi memang mempunyai kelebihan ketika merepresentasikan perempuan dibandingkan dengan iklan di majalah, surat kabar, atau film. Di televisi, iklan dapat ditayangkan dengan frekuensi yang tinggi (sering) sekalipun dengan durasi yang singkat. Selain itu, pesan yang disampaikan dapat dikemas sedemikian rupa untuk dapat "menembak" dengan jitu pada benak konsumen.

Di sinilah letak permasalahannya. Iklan yang ditayangkan di televisi hampir semuanya memajang perempuan sebagai model iklan. Ken Sudarto (dalam Astuti, 2004:315) menjelaskan bahwa pertimbangan penggunaan model iklan perempuan, semata-mata atas pertimbangan efektivitas pesan yang ingin dikonsumsikan. Kemudian, kelompok sasaran akan tergerak dengan adanya sosok perempuan dalam produk yang diiklankan, maka hal ini merupakan dasar keputusan untuk menggunakan perempuan sebagai model iklan. Pada sisi lain, Priosoedarsono (1998) berpendapat bahwa tampilnya wanita dalam iklan memang dibutuhkan untuk memperkuat daya jual dari sebuah produk, bukan saja dalam menyampaikan sebuah pesan, tetapi juga kesan terhadap produk tersebut.

Untuk itu, kita dapat melihat hasil penelitian mengenai representasi perempuan dalam iklan yang dilakukan oleh Dyer (dalam Strinati,2004:213)) terhadap 170 iklan yang ditayangkan di televisi. Hasil penelitian menemukan, 66 persen figur sentral dalam iklan keuangan ... adalah laki-laki atau “diperdengarkan suara” laki-laki. Pada seluruh iklan, laki-laki digambarkan sebagai sosok mandiri; sementara, perempuan digambarkan sebagi sosok yang bergantung. Secara tipikal, laki-laki digambarkan "memiliki keahlian dan wewenang", bersikap objektif dan memiliki pengetahuan tentang berbagai produk; sedangkan kaum perempuan, secara tipikal ditampilkan sebagai konsumen produk-produk tersebut. Kemudian, suara laki-laki di belakang layar digunakan pada sebagian besar produk yang diiklankan.

Oleh karena itu, Dyer menyimpulkan bahwa perlakuan perempuan dalam iklan, bermuara pada apa yang disebut oleh seorang peneliti Amerika sebagai "anihilasi simbolis" perempuan. Dengan kata lain, iklan mencerminkan nilai-nilai sosial yang dominann; perempuan tidak penting kecuali di 
rumah; bahkan, laki-laki tahu yang terbaik, sebagaimana yang ditunjukkan oleh suara-suara laki-laki untuk produk-produk kaum perempuan. Ketika perempuan diangkat dalam iklan yang diperlihatkan adalah sisi kebergantungan (emosi), tubuh, kecantikan, dan lain-lain yang bersifat stereotif.

Dari penjelasan tersebut, maka kita dapat melihat indikator dipajangnya perempuan sebagai model iklan adalah ditujukan untuk memancing afeksi - reaksi yang emosional dari konsumen, khususnya laki-laki. Maka, tidak heran jika iklan oli 'Top one", misalnya, memajang perempaun cantik dan seksi sebagai model iklan. Padahal, iklan tersebut tidak ada hubungannya dengan oli mobil yang mempunyai segmen pasar laki-laki. Lihat juga iklan rokok "Jarum Coklat" yang jelas-jelas ditujukan untuk laki-laki, namun tetap menggunakan model iklan perempuan yang cantik dan seksi sebagai pajangan untuk menarik secara emosional pihak laki-laki.

Dalam konteks citra perempuan dalam iklan yang banyak ditayangkan televisi, maka cerita budaya berusaha untuk dibangun dengan menampilkan manipulasi tubuh wanita (outer body of women) yang menjadi sebuah tanda atau makna tertentu dari simbol-simbol tertentu yang mungkin secara stereotifmelekat pada perempuan tersebut, seperti keanggunan, keindahan, kelembutan, kemanjaan, dan mungkin banyak lagi

Dengan demikian, kita sepertinya dibombardir oleh iklan-iklan yang bermodel perempuan cantik dan seksi. Celakanya, perempuan ditempatkan hanya sebagai pajangan. Pada sebuah kesempatan diskusi, Nurul Arifin artis yang punya perhatian terhadap masalah perempuan, mengeluhkan banyaknya iklan-iklan yang hanya memaperkan kemolekan tubuh dan kecantikan wajah wanita.

Maraknya penggunaan perempuan sebagai model iklan, diakibatkan oleh adanya budaya patriakhal. Liesbet van Zoonen (dalam Ibrahim,2001;191) menyatakan bahwa elemen utama dalam budaya partriarkhal barat adalah display wanita sebagai tontonan untuk dilihat, ditujukan untuk tatapan khalayak (pria), sehingga, tak heran bila Laura Mulvey punya pendapat bahwa wanita di display hanya untuk tatapan dan kenikmatan pria.

Bila kita tarik pada rumus iklan yang baik, maka sebetulnya sebuah iklan harus memperhatikan pada beberapa elemen yang harus ada sebagai syaratnya. Elemen - elemen yang kita dikenal dengan rumus AIDCA, yang terdiri dari :

(1) Attention ( perhatian )

(2) Interest ( minat)

(3) Desire (kebutuhan/ keinginan )

(4) Cinviction ( rasa percaya)

(5) Action ( tindakan ) (Kasali, 1995: 83).

Tahapan dari rumus AIDCA dapat dijabarkan sebagai berikut :

(1) Tahap attention. Iklan harus dapat menarik perhatian dari khalayak sasaran terhadap produk maupun jasa yang diiklankan. Agar iklan itu bisa menarik perhatian khalayak, iklan tersebut memerlukan bantuan berupa ukuran, penggunaan warna, tata letak, jenis - jenis huruf yang ditampilkan serta suara - suara khusus.

(2) Tahap berikutnya adalah interest, yaitu calon pembeli setelah berhasil direbut perhatiannya. Maka persoalan berikutnya adalah bagaimana agar mereka berminat dan ingin tahu lebih jauh. Untuk itu, mereka harus dirangsang agar mau membaca dan mengikuti pesan - pesan yang disampaikan.

(3) Tahap desire. Iklan tersebut harus dapat menumbuhkan orang dari sisi kebutuhannya untuk memiliki atau menikmati produk yang diiklankan. Kebutuhan atau keinginan mereka untuk memiliki, atau melakukan sesuatu harus dibangkitkan.

(4) Sampai pada tahap ini, produsen telah berhasil menciptakan kebutuhan calon pembeli. Pada tahap cinviction ini juga, rasa percaya terhadap produk yang ditawarkan dibutuhkan oleh orang untuk mengambil keputusan. Untuk menimbulkan rasa percaya pada diri calon pembeli, sebuah iklan dapat ditunjang berbagai kegiatan peragaan seperti testimonial atau pembuktian, membagi - bagikan contoh secara gratis.

(5) Upaya terakhir untuk membujuk calon pembeli 
agar sesegera mungkin melakukan suatu tindakan pembelian yaitu dengan memilih kata yang tepat agar calon pembeli bergerak melakukan respons sesuai dengan yang diharapkan. Inilah tahap akhir dalam proses periklanan yang dikenal dengan tahap action atau tindakan nyata yang diperlihatkan oleh para konsumen.

Memang sejatinya kandungan iklan terdiri dari dua aspek, seperti dijelaskan sebagai berikut:

Pertama, tampilan visual dan kedua bahasa. Oleh para kreator iklan, kedua aspek ini diolah agar iklan-iklan yang muncul enak dilihat serta mengena pada sasaran yang dibidik. Selama ini, kecuali pada iklan radio, para pekerja kreatif iklan tampak lebih mengekspresikan gagasannya pada aspek visual. Apalagi hal ini kemudian didukung oleh ketersediaan teknologi multimedia yang canggih. Akibatnya, kreativitas tampilan visual iklan terlihat lebih menonjol dibanding aspek bahasa yang banyak dibebani berbagai ketentuan kebahasaan atau etika (Majalah Cakram, edisi Mei 2003).

Di sisi lain, Bovee ( 1976 ) mengemukakan, bahwa periklanan yang baik mengacu pada segi daya tarik bagi iklan yang terdiri atas: daya tarik pesan dalam artian kata-kata, kalimat; dan berikut daya tarik fisik, yaitu penampilan luar, ilustrasi yang menyertai iklan itu (dalam Liliweri, 1992:75).

Melihat pada rumus AICDA dan apa yang telah dijelaskan di atas, seharusnya sebuah iklan tidak hanya mengandalkan pada ekploitasi tubuh wanita sebagai model iklan, karena masih banyak lagi faktor penting yang harus diperhatikan. Namun, sekali lagi, kenyataan di lapangan membuktikan bahwa model wanita dengan kecantikan dan keseksi-an tubuhnya seolah menjadi alat ukur menarik tidaknya iklan yang ditayangkan di televisi.

Meminjam istilah Marwah Daud Ibrahim (dalam Ibrahim, 1997:104) seks itu indah, maka yang terjadi adanya pengukuhan stereotif bahwa seks atau ke-seksi-an identik dengan perempuan. Menurutnya, hal ini disebabkan oleh berapa faktor, yaitu; pertama, karena chain of activities media massa di Indonesia seperti juga hampir di seluruh dunia dikuasai oleh lelaki. Dengan kata lain, pemaknaan terhadap representasi perempuan dalam iklan akan ditentukan oleh mereka. Kedua, dengan adanya pemaknaan pada diri mereka tentang keindahan, kecantikan, kelembutan dan lain sebagainya, yang menjadi melekat pada diri perempuan, akan mempengaruhi ketika laki-laki mengintip melalui lensa kamera.

\section{Daftar Pustaka}

Astuti, Santi, Indra. 2004. "Representasi Perempuan Indonesia dalam Komunikasi Visual: Wacana yang (Belum) Berubah”, MediaTor. Volume 5 Nomor 2.

Barker, Chris. 2005. Cultural Studies: Teori dan Praktek. Penerjemah Tim Kunci Cultural Studies Center, Bentang, Yogyakarta.

Chaney, David. 1996. Lifestyles: Sebuah Pengantar Komprehensif. Penerjemah Nuraeni, Yogyakarta: Jalasutra.

DeVito, Joseph. A. 1978. Communicology: An Introduction To The Study Of Communication. New York: Harper \& Row Publisher,

Effendy, Onong Uchjana. 1986. Dimensi-Dimensi Komunikasi. Bandung: Alumni. 2000. Ilmu, Teori dan Filsafat Komunikasi. Bandung: PT Citra Aditya Bakti.

. 2002. Dinamika Komunikasi. Bandung: PT. Remaja Rosda Karya.

Fiske, John. 1990. Cultural and Communication Studies. Penerjemah Yosal Iriantara dan Idi Subandi. Yogyakarta: Jalasutra,

Ibrahim, Idi Subandy. 1997. Lifestyle Ecstacy: Kebudayaan Pop dalam Masyarakat Komoditas Indonesia. Yogyakarta: Jalasutra.

Jefkins, Frank. 1997. Periklanan. Jakarta: Erlangga.

Kasali, Rhenald. 1995. Manajemen Periklanan. Jakarta: PT Pustaka Utama Grafiti. 
Kuswandi, Wawan. 1996. Komunikasi Massa Sebuah Analisis Media. Bandung: Remaja Rosdakarya.

Liliweri, Alo. 1992. Dasar-Dasar Komunikasi Periklanan, Bandung: Citra Aditya Bakti.

Mulyana, Deddy. 2001. Ilmu Komunikasi-Suatu Pengantar. Bandung: ROSDA.

Mulyana, Deddy dan Jalaludin Rakhmat. 2003. Komunikasi Antar Budaya. Bandung: Remaja Rosda Karya.

Rahmadi, F. 1990. Perbandingan Sistem Pers. Jakarta: PT Gramedia.
Rakhmat, Jalaluddin. 1996. Psikologi Komunikasi: Edisi Revisi. Bandung: Remaja Rosdakarya.

Strinati, Dominic. 2004. Popular Culture: Pengantar Menuju Teori Budaya Populer. Penerjemah Abdul Mukhid, Yogyakarta: Bentang.

Suhandang, Kustadi. 2005. Periklanan; Manajemen, Kiat, dan Strategi. Bandung: Penerbit Nuansa.

Susanto, A.B. 2001. Potret-Potret Gaya Hidup Metropolis, Jakarta: Penerbit Buku Kompas.

\section{Sumber Lain:}

Majalah Cakram Komunikasi, Edisi Mei 2003. 
